\title{
IN LINE WITH BRUSSELS. ROMANIAN AND BULGARIAN POSITION ON THE UKRAINIAN CRISIS
}

\author{
Aneta Mihaylova, PhD \\ Institute of Balkan Studies \& Centre of \\ Thracology, Bulgarian Academy of Sciences \\ Bulgaria \\ aneta.mihaylova@gmail.com \\ Plamen Dimitrov, PhD \\ Bulgarian Geopolitical Society \\ Bulgaria \\ Plamen127@mail.bg
}

\begin{abstract}
The Ukrainian crisis has been a test for the alignment of Romania and Bulgaria with the EU on the background of the Union's new foreign policy instruments as redesigned by the Lisbon Treaty. This paper aims to present the positions of Bulgaria and Romania towards the events of 2013-2015 in Ukraine. Our research target is to identify the driving forces that shaped these positions, to analyse and describe the main foreign policy goals and actions of Bucharest and Sofia regarding the Russian-Ukrainian conflict, and to compare the attitude of these two countries toward the Ukrainian crisis.

The paper analyses first the Romanian and the Bulgarian perspectives on the dramatic events in Ukraine in the first half of 2014. The positions of the two countries are further placed in the wider international context of the Ukrainian crisis - the UN resolutions, the EU sanctions against Russia, NATO activities, and the security in the Black Sea region. In the third part Romania and Bulgaria are viewed as a "playground" for the competing narratives and propaganda in regards to the Russian-Ukrainian conflict. We also examine the economic impact
\end{abstract}


of the crisis on the two Balkan countries, as well as the efforts of both Bucharest and Sofia to protect their respective minorities in Ukraine. In conclusion, we summarize the results of our research and explain how the Ukrainian crisis has reshaped the foreign policy debates in Romania and Bulgaria.

\section{Keywords}

Bulgaria, EU foreign policy, Romania; Russian propaganda, sanctions against Russia, Ukrainian crisis

\section{INTRODUCTION}

The Ukrainian crisis was the first serious and prolonged geopolitical conflict that occurred in Europe after Bulgaria and Romania joined the EU in 2007. It was a test for the new member states alignment with the EU on the background of the Union's new foreign policy instruments as redesigned by the Lisbon Treaty. The crisis in Ukraine had a very strong impact on Romania given the fact that it is a country bordering Ukraine and has a significant Romanian speaking minority there. Yet, the factor that most strongly influenced Romanian interest in the conflict was the concern with the possible consequences of the events in Ukraine for its neighbour Moldova, which holds a special place in Romanian foreign policy priorities.

If we consider the relationship between Romania and Ukraine after 1989, it is apparent that they were far from smooth. For almost two decades, the two countries had disagreements on the delimitation of the continental shelf and the status of the Snake Island, which was resolved, favourably to Romania, only in 2009, with the assistance of the International Court in the Hague. They also clashed on economic and environmental issues in the area of the Danube River (Kruglashov 2011).

The relations between Bulgaria and Ukraine have always been interconnected with the controversial and enduring impact Russia (the former Soviet Union) has had upon Bulgarian history. The reason for that is the fact that for a significant part of the last two centuries Ukraine was incorporated as part of the Russian 
Empire and then of the USSR. Even after the dissolution of the Soviet Union, it was difficult for many Bulgarians to differentiate between Ukraine and Russia. The strongest link connecting Bulgaria and Romania with Ukraine comes from the Bulgarian and Romanian minorities on the Ukrainian territory. Both the Romanians and the Bulgarians in Ukraine have their own cultural associations and media and have their representatives in the Ukrainian parliament. Many of them have obtained either a Romanian or a Bulgarian passport regardless of the fact that in Ukraine dual citizenship is forbidden by the law.

This article aims to present the positions of Bulgaria and Romania with regard to the events of 2013-2015 in Ukraine. Our research target is to identify the driving forces that shaped these positions, to analyse and describe the main foreign policy goals and actions of Bucharest and Sofia in regards to the RussianUkrainian conflict, and last but not least - to compare the attitude of these two countries toward the Ukrainian crisis, calling attention to both the similarities and differences.

The research will be based on qualitative methods of foreign policy analysis. We shall examine the legal acts, official statements of the Prime Ministers, the Presidents, the leaders of the parliamentary political parties and other public figures, as well as data from sociological surveys that concern the geopolitical orientation of Bulgarians and Romanians.

Based on the rational actor model, the state with its respective institutions will be the main unit of analysis. As such, Romania and Bulgaria are seen in this approach as rational players for conducting their own foreign policy decisions. At the same time, we share the assumption that they act also as units of the other rational player - the European Union. As such, a certain level of coordination between their foreign policy decisions and EU's position is expected.

The chronological and thematic approaches will be combined. In the first part of this article we are going to analyse the Romanian and the Bulgarian perspectives of the dramatic events in Ukraine in the first half of 2014 - the Euromaidan, the annexation of Crimea by Russia and the beginning of the armed conflict in Donbas. Further, the position of Romania and Bulgaria will be placed in the wider international context of the Ukrainian crisis - UN resolutions, the EU sanctions against Russia, NATO activities, and the security in the Black Sea 
region. In the third part we will look at Romania and Bulgaria as a "playground" for the competing narratives and propaganda in regards to the RussianUkrainian conflict. We will review the economic impact of the crisis on the two Balkan countries. Finally, we are going to explore the efforts of both Bucharest and Sofia to protect their respective minorities in Ukraine. In conclusion, we will summarize the results of our research and explain how the Ukrainian crisis reshaped the foreign policy debates in Romania and Bulgaria.

\section{THE EUROMAIDAN, CRIMEA REFERENDUM, AND THE ARMED CONFLICT IN DONBAS FROM ROMANIA'S AND BULGARIA'S PERSPECTIVES}

Located on the eastern border of the EU, Romania is interested in having a stable neighbourhood and has supported EU policies and initiatives in the region and the integration of the former Soviet republics in the EU. Therefore, the decision of the Ukrainian President, Viktor Yanukovych, to reject the Association Agreement of Ukraine with the EU in November 2013 caused frustration in Romania and also concern that this could adversely affect the European path of Moldova (Ilie 2014).

Initially, Romania refrained from expressing a definitive view on what was happening on the Euromaidan. With the escalation of the conflict in Ukraine, however, Bucharest's position was quickly articulated and combined with seeking guarantees for its national security and the preservation of the territorial integrity and European future of Moldova. In addition, Romania made efforts to strengthen its international position.

Unlike Romania, the attitude of Bulgaria in regard to the Ukrainian crisis passed through different stages depending on the internal dynamics of the political processes in Ukraine, but also on the change of the ruling majority in Sofia. During the period from the end of 2013 until the middle of 2015, Romania was ruled by one single government, that of Victor Ponta, while in Bulgaria there were three changes of government - Plamen Oresharski, Georgi Bliznashki and 
Boyko Borisov. During the whole period of the Ukrainian crisis, the President of Bulgaria was Rossen Plevneliev, who won the position as a GERB (Citizens for the European Development of Bulgaria) candidate, whereas Romania had two presidents - Traian Băsescu until December 2014 and Klaus Iohannis after that. Having in mind the change of governments, we can expect Bulgaria's policy toward the Ukrainian crisis to be more volatile than Romania's.

In the first part of 2014, when Russia annexed Crimea, the war in Donbas began, and the EU imposed its first sanctions against Moscow, the Bulgarian Parliament was dominated by a coalition between the Bulgarian Socialist Party (BSP) and the Movement for Rights and Freedoms (MRF) - the party of Bulgaria's Turkish minority, supported at critical moments by the representatives of the nationalist pro-Russian party "Ataka". GERB (a member of the right-wing European People's Party, EPP) was in opposition.

From the beginning of Euromaidan until the fall of Yanukovych, there was not an active Bulgarian position regarding the events in Ukraine. In early December 2013 the Foreign minister, Kristian Vigenin, demonstrated caution, declaring that Sofia would wait until a joint position of the EU member-states on the events in the Ukrainian capital was adopted (24 chasa 2013). Nevertheless, a week later he made it clear that Bulgaria supported closer relations between Ukraine and the EU and that the Association Agreement between Kiev and Brussels should be signed in the near future. Within this context, we can agree with the assessment of Dariusz Kalan from the Foreign Affairs magazine who describes the Bulgarian line during the Euromaidan as a "do nothing" policy" (Kalan 2015).

After series of bloody clashes between the protesters and the security forces in Kiev, on February 20, 2014 the EU agreed to impose sanctions on Ukrainian officials "responsible for violence and excessive force" (BBC News 2014). Since such a decision could only be taken unanimously, it meant that Romania and Bulgaria had also voted for it. On the same day (20 February) 9 out of 17 Bulgarian members of the European Parliament declared a joint position, in which they expressed support for the protesters in Kiev and appealed for "a creation of new government of unification, early presidential elections and constitutional reforms in Ukraine". This position had been subscribed to by the Bulgarian members of the EU Parliament who were part of the EPP (GERB and 
the Blue coalition) and the Alliance of Liberals and Democrats (NMSS, but not the representatives of the MRF who were from the same group in the EP) (Dnevnik 2014).

The developments in Kiev in the period 21-23 February 2014 were very quick and the passive Bulgarian state institutions were not able to formulate a clear position upon the dramatic political change in Ukraine. However, at the beginning of March, Bulgaria gave a signal that it recognized the new power in Kiev. The Foreign Minister, Vigenin, visited Ukraine and had meetings with his Ukrainian colleague, Andrii Deshchytsia, as well as with the acting president, Turchinov, and declared that Bulgaria "supports the sovereignty and the independence of Ukraine" (Club Z 2014).

The visit of the Bulgarian foreign minister to Ukraine irritated the "Ataka" party which had representatives in the parliament. The main characteristic of this party was and still is its strong support to the politics of Russia and the president Putin. The visit of Vigenin to Ukraine was, however, also criticized by some prominent members of his own party. There was an internal division within the ranks of this party - the larger part of its electorate supported Russia in the conflict with Ukraine but, at the same time, the party leadership's position was closer to the EU's position which was definitely not pro-Russian. It is important to emphasize that the then leader of the BSP, Sergei Stanishev, was also the chairman of the Party of European Socialists (PES).

Comparing to Bulgaria, Romania adhered strictly to the EU position on the crisis and, at the same time, it tried to establish itself as an active regional player in its resolution. On March 1, 2014, after a meeting with representatives of the national security institutions, President Traian Băsescu declared that Romania would not raise the level of alert for its national security institutions in connection with the situation in Crimea, but would monitor very closely the situation in Ukraine and the separatist tendencies in the Republic of Moldova. A few days later, at the Brussels summit on March 6, 2014, the Romanian President took an even stronger position, saying that "what Russia has done in Ukraine was an aggression against that country" and called on the US and Britain to fulfil their obligations as guarantors of the security and territorial integrity of Ukraine. He stated Romania's desire both as a country adjacent to Ukraine and as the EU 
member state closest to Crimea to participate in the negotiations to resolve the conflict between Kiev and Moscow. Băsescu also pointed to the fact that Romania was not dependent on imports of Russian gas, which eliminated the possibility of pressure in the negotiations (Toea 2014c). The Romanian Prime Minister Victor Ponta, for his part, made a statement that Romania would not and should not engage in separate actions in Ukraine, but emphasized that its position was "perfectly consolidated" with that of its partners in the EU and NATO (Badea 2014).

In March 2014, the focus of the Ukrainian crises shifted to Crimea. Bulgaria did not recognize the legitimacy of the annexation of Crimea by Russia. This was declared on the eve of the referendum by the foreign minister Vigenin and the President Plevneliev. The position of S. Stanishev was expressed on the web-site of the PES, where he wrote: "The referendum does not correspond to international law and it is illegal under the Ukrainian constitution. Furthermore, the territorial integrity and sovereignty of Ukraine are being put at risk. The PES believes that Russia's intentions to annex Crimea sets a dangerous precedent that could lead to further destabilization of the region" (PES 2014). Five members of the Bulgarian parliament, all of them from the "Ataka" party, were present at the referendum in Crimea as observers. On March 16, 2014, the day the referendum in Crimea was held, President Băsescu expressed the resolute position of his country that it considered it illegal and would not recognize its results (Ziare.com 2014b).

Immediately after the referendum in Crimea, Bulgaria and Romania backed the EU's decision to impose restrictive measures against 21 Russian and Ukrainian officials responsible for the actions threatening Ukraine's territorial integrity (Regulation (EU) 2014).

In March 2014, it became clear that there was no concord over the Ukrainian crisis in the Bulgarian Parliament. Three completely different resolutions on the developments in Ukraine were proposed. The opposition party, GERB, insisted that the MPs should confirm the illegitimacy of the Crimean referendum and support the territorial integrity of Ukraine. At the opposite political pole was the "Ataka" party. It proposed a resolution in which "armed terrorists financed from 
abroad" acting in Kiev were mentioned and the new authority in Ukraine was defined as illegitimate ("Ataka" 2014).

The real "drama" took place within the ranks of the biggest ruling party - BSP. Originally, its leader, Stanishev, had proposed a resolution appealing for the withdrawal of the Russian troops from Crimea to the places of their permanent dislocation in the military base of Sevastopol. In that document, there was a clear expression of support for the territorial integrity of Ukraine. However, two days later, the Plenary Assembly of the Socialist party completely rewrote this resolution. In the new version, there was no mention of the Russian troops in Crimea. Instead, there was a proposal for the EU to defer the signing of the Association Agreement with Ukraine pending the forthcoming elections (Mediapool 2014). In the end, the Bulgarian Parliament failed to adopt a joint resolution on the Ukrainian events because of the lack of concord between political parties.

Meanwhile Nikolay Malinov - an influential member of the Parliament from the Socialist party, speaking about the referendum in Crimea on Bulgarian National Television, offered his congratulations to "the victory in the Third Crimean War of all Orthodox Slav peoples of the world"(Dnevnik 2014b).

On March 24, 2014, a session of the Consultative Council for National Security (CCNS) under the Bulgarian President took place. The theme of the session was "Risks for Bulgaria that emerged from the development of the Ukrainian crisis". With one exception - the leader of the "Ataka" party - all members of the Council expressed their support for the territorial integrity of Ukraine and declared that Bulgaria would act as a member of NATO and the EU. At the same time, the CCNS insisted that the Ukrainian authorities should respect the rights of all Ukrainian citizens, including the Bulgarian minority (Cross 2014).

Romania welcomed the consensus reached at the European Council meeting on March 21, 2014 to deploy a monitoring mission of the OSCE in Ukraine, describing it as an important step in the efforts towards resolving the crisis. In a statement by the Romanian Ministry of Foreign Affairs, it was underlined that the country would explore the opportunities to provide full assistance in the establishment of the mission and would act consistently with regard to the full and effective implementation of that decision. It expressed the principled 
position of Romania to preserve the territorial integrity of Ukraine and its sovereignty within its internationally recognized borders as a fundamental element in maintaining regional stability and security. (Ministry of Foreign Affairs 2014c)

\section{SANCTIONS, NATO, AND REGIONAL SECURITY - ROMANIA'S AND BULGARIA'S POSITION AFTER THE INTERNATIONALIZATION OF THE UKRAINIAN CONFLICT}

Romania and Bulgaria voted in favour of both Resolution 262 of the UN General Assembly on March 27, 2014, condemning Russia's actions in Crimea and of Resolution 1990 of the Parliamentary Assembly of the Council of Europe (PACE) of April 10, 2014 for suspension of the voting rights of the Russian delegation in the Assembly. As members of the organization, Romania and Bulgaria supported NATO's decision of March 17, 2014, to cease any practical cooperation with Russia. However, by 2014, Bulgaria and Romania saw the role of NATO in the Black Sea region in a different way. The politicians from the ruling coalition in Sofia did not see a direct threat from Russia to the national security of Bulgaria. In Romania it was exactly the opposite position. After Russia's annexation of Crimea, Romanian state officials insisted that in response to Russian expansionism in the region the US and NATO should increase their military presence in the Black Sea and on the territory of Romania itself and thus ensure the national security of the country. President Băsescu, only a week after the annexation, stated that after Russia's annexation of Crimea NATO had to redeploy its forces (Serban 2014). The call for the strengthening of NATO's role and presence in the region were heard from a number of Romanian politicians from across the entire political spectrum. The President of the Romanian Senate, Calin Popescu-Tăriceanu, considered the reaction of the West to the extremely tense situation in neighbouring Ukraine as too weak, and urged Romania to make a formal request to be included, along with the Baltic states and Poland, among the countries which were directly threatened by the expansion of the 
conflict in Ukraine that implied the need for additional guarantees for its security (Ziare.com 2014a). During his visit to the US, in late April 2014, the Romanian foreign minister, Titus Corlățean, spoke at a conference in Washington on the need to strengthen collective defence within NATO in the context of the tension in the region and called for a permanent military presence of NATO/USA in the Black Sea (Ministry of Foreign Affairs 2014b).

Romania was among the most resolute supporters of the Western sanctions against Russia. During the crisis, it constantly insisted on furthering the list of sanctions and called on the European institutions to show greater firmness and determination with regard to Moscow. The Romanian government declared itself against any act of separatism and condemned Russia's actions in eastern Ukraine. In a message of the presidential administration, at the end of April 2014, Romanian President Traian Băsescu urged the Russian President Vladimir Putin to "firmly condemn the illegal military actions" in the Ukrainian Donetsk region and to use all his authority to ensure the smooth functioning of the OSCE mission in eastern Ukraine. He also stressed that Romania condemned separatism and any use of military pressure in resolving political demands (Hotnews.ro 2014). A statement from the Romanian Ministry of Foreign Affairs of May 11, 2014 pointed out that Romania again called on Russia not to recognize the so-called referendum organized by the pro-Russian separatists in their bastions in the Donetsk and Luhansk regions in eastern Ukraine, to respect the territorial integrity and sovereignty of Ukraine, and to return to the framework of international law, including immediate withdrawal from Crimea (Ministry of Foreign Affairs 2014a).

The spread of the conflict to the Odessa region increased Romania's anxiety, because the theatre of operations was approaching the both borders of Moldova and its own borders. On May 13, 2014, after consultations with the Prime Minister, Victor Ponta, and members of the government, President Traian Băsescu released a special statement regarding the tense situation in the region. The President stated that, after the Russian intervention in the region there was a greater risk of federalization and added that dialogue between the government in Kiev and the separatists in eastern Ukraine was absolutely necessary, while noting that the pro-Russian representatives of the rebel areas must not 
participate in any international negotiations. He also emphasized that Russia wanted the federalization of Ukraine in order to effectively place it under Russian control and warned that the destabilization of the Odessa region might extend Russian influence even to Romanian territory (Toea 2014b).

During the meeting of the Heads of States of Central and Eastern Europe in Warsaw, on July 22, 2014, Romanian President, Traian Băsescu, again urged NATO to redeploy its resources because of the Russian military manoeuvres. At a conference in London discussing NATO and European security in early September 2014, the Romanian foreign minister, Titus Corlățean, reiterated the position that the country insisted upon the necessity of a permanent and lasting presence on its eastern flank and expressed full support for a NATO presence in Romania (Agerpres 2014f).

Romania was very active also at the NATO Wales summit on September 5, 2014. After his return from Newport, the Romanian President Băsescu stated that his country was successful in obtaining a plan of contingency and action plans in case of some attack by land, air or water. He emphasized that the Ukrainian conflict might be extended to Romania if Russia took "irrational actions." In his view, "although the likelihood of Romania not being attacked by Russia was 99.9 percent, it had to be ready for the remaining 0.01 percent" (Agerpres 2014e).

Romania's stance on the sanctions against Russia remained unchanged after the changing of president. On December 19, 2014, after the European summit in Brussels dedicated to EU relations with Moscow, and prior to his official inauguration, the new Romanian president, Klaus Johannis stated that he supported the need to maintain dialogue with Russia, but believed that international sanctions should be maintained as long as the sovereignty of Ukraine was being placed in jeopardy. At the end of January 2015, at a meeting of EU foreign ministers, the Romanian foreign minister, Bogdan Aurescu, insisted again on the strengthening of the regime of sanctions against Russia. His arguments for that were the serious deterioration in the security context and the existence of "certain proof" of direct involvement of Russia in support of the separatists in eastern Ukraine (Agerpres 2015b).

Without a clear position in the National Assembly, the policy of Bulgaria toward the Ukrainian crisis was established by the government and, in particular, by the 
Ministry of Foreign Affairs. In general, Sofia was a predictable partner in the EU and did not indicate that it would jeopardize the European consensus on the Ukrainian crisis. However, in contrast to Romania, Bulgaria was not in the group of the countries that insisted upon stronger pressure against Russia.

In 2014, the Ukrainian conflict was one of the international themes affecting Bulgarian society. A sociological survey of April 2014 showed that the percentage of Bulgarians supporting Russia in the conflict with Ukraine exceeded, by a small margin, those supporting Kiev. To the question "Do you approve the accession of Crimea to Russia" 35\% answered "yes", 27 - "no", and 38\% - "I don't know" (Gallup International 2014).

The Bulgarian position on the Ukrainian crisis became more pro-Ukrainian after the summer of 2014, with the resignation of the government dominated by the Socialist party. In the caretaker government of Georgi Bliznashki, which took power on August 6, 2014, the posts of the foreign and defence minister were given the politicians with a clear Euro-Atlantic profile. The situation did not change when the new regular government dominated by GERB party took office in November 2014.

Under the guidance of Minister Velizar Shalamanov, a politician with strong proEuro-Atlantic orientation, the Ministry of Defence prepared a document entitled "Vision 2020: Bulgaria in NATO and in European Defence". The aim of this document was to define Bulgaria's position for the NATO Wales summit. In the initial version of "Vision 2020", the Ukrainian crisis was explained as part of "the long-term ambition of Russia to restore its influence in the post-Soviet space". In the document, it was noted that Bulgaria was a target of hybrid warfare through the "active propaganda of Russian politics with the mediation of Bulgarian political and economic entities and NGOs" (Capital 2014b). The provisional document was sharply criticized by the pro-Russian political parties but also by the leader of GERB, Boyko Borisov, and by the caretaker Prime Minister Bliznashki. In the end, the Security Council to the government adopted a revised version of "Vision 2020", where Russia was already not being identified as a threat to Bulgaria's national security, but, nonetheless, the "unlawful annexation of Crimea by the Russian Federation" was mentioned (Capital 2014a). 
In May 2015, in reply to a parliamentary inquiry about the sanctions against Moscow and its counter-sanctions, the Bulgarian Prime Minister, Boyko Borisov, said that Bulgaria "is suffering serious losses from this policy", but cannot adopt "a position different from that of the EU and NATO" (Mediapool, 2015b). In contrast to Borisov, the President, Plevneliev, and the Foreign Minister, Mitov, emphasized more categorically Russia's responsibility for the events in Ukraine and the deterioration of the security environment in the Black Sea Region. During his official visit to Kiev, in July 2015, the Bulgarian Head of State had a meeting with his Ukrainian counter-part, Petro Poroshenko, and declared: "For us Crimea is Ukraine, and Ukraine is Europe!" (Mediapool 2015a).

In the case of Boyko Borisov, his deep respect for the Chancellor of Germany, Angela Merkel, had a strong influence on his foreign policy positions. In this respect, M. Lessenski has remarked very precisely that, as far as the RussiaUkraine conflict is concerned, Bulgaria is a part of a peculiar "coalition of the willing" formed and led by Germany (Lessenski 2015, 11; for the leading role of Germany, see for example Gediminas 2015, 12-13).

\section{HISTORY AND PROPAGANDA - THE UKRAINIAN CRISIS IN THE CONTEXT OF TRADITIONAL RUSSIAN-ROMANIAN AND RUSSIAN-BULGARIAN RELATIONS}

The crisis in Ukraine exacerbated the traditionally hostile relations of Romania with Russia, which suffer from the historical burden of the longstanding territorial dispute over Bessarabia. In the period after 1989, there were some efforts for normalization of the relations between the two countries, but they were again clouded after Russia openly sided with the breakaway Transnistrian region of the Republic of Moldova and, in the following years, the two countries were in constant rivalry for influence in Moldova. Yet, undoubtedly one of the most important issues in Russian-Romanian relations was Romania's decision to authorize the deployment of elements of the US air defence on its territory. Russia has regarded with deep suspicion the building of bases for the NATO 
missile defence system, one of which is located on the territory of Romania. While Romania regarded the program for missile defence based in Europe as a guarantee of the US commitment to the region, for the Russians that was simply the first phase of a wider US deployment along the borders of the Russian sphere of influence (Kirilov 2012).

In fact, what worried most Romania, since the initial stage of the crisis in Ukraine, were the potential hazards for Moldova and, in particular, the possibility for it to ignite conflict in its Russian-language breakaway region of Transnistria, which was only formally a part of Moldova, and which, had Russian troops stationed on its territory. However, with the escalation of tension in Ukraine in late February - early March 2014, when the attention was focused on the events in Crimea, there were many publications in the Romanian media about the possibility of an immediate military threat to the country from Russia. For a long time, the crisis in Ukraine occupied the front pages of most of the Romanian newspapers, like, for example, "Adevărul", "România Liberă" and "Evenimentul Zilei". The Romanian government continued to insist that Russia was the main source of conflict and instability but, at the same time, tried to reassure the public that there was no threat of possible conflict with Russia. In the tense atmosphere after the annexation of Crimea, when Transnistria had also expressed its desire to join the Russian Federation (Milevska 2014), the Romanian foreign minister, Titus Corlățean, stated that being in NATO, Romanians had nothing to worry about. The same argument was used also by the Prime Minister Victor Ponta and the President Traian Băsescu (Serghescu 2014; Zachmann 2014). In May 2014, the two countries were facing a potential diplomatic conflict when Romania, following the example of Ukraine, also decided to close its airspace to the aircraft of the Russian Deputy Prime Minister, Dmitry Rogozin, upon his return from the capital of the unrecognized republic of Transnistria. The Russian official warned, on his Twitter account that next time he would fly over Romania at the board of a TU-160. Rogozin and the former President Basescu exchanged bitter remarks in the press and the Romanian authorities demanded clarification in relation to whether Rogozin's comments were the official position of Russia towards Romania, a NATO and EU member state (Agerpres 2014g). 
The tension in Russian-Romanian relations was reflected in the media of both countries. In the Romanian press as a whole, Russia was presented as an enemy and a serious threat to the security of the country. In the Russian press, Romania was accused of trying to exploit the situation in Ukraine to assert its territorial claims to it and that its territory was used as a staging ground for the war against Russia (Sputnik France 2014, The Voice of Russia 2014, Mândrăşescu 2014).

At the same time, Russian propaganda was making its way into Romania. Since March 2014, the Russian media enhanced the spread of news in the country about Romania through the radio "Voice of Russia" which also broadcast in Romanian. At the end of 2014, a new news website in Romanian, RussiaToday.ro, was launched as an offshoot of RT (Inayeh 2015). Despite Russia's efforts to influence public opinion, Romanian society remained immune to Russian propaganda. The traditional distrust towards Russia among the population at large has been further increased with the events in neighbouring Ukraine. A survey of Romanian sentiment toward other countries conducted by the Romanian Institute for Social Research INSCOP in July 2014 placed Russia as the country least well-regarded, with only 37 percent of the respondents expressing a positive attitude to it (INSCOP 2014).

Although Bulgaria is not a member with much influence in the EU, it has become an object of the information war between Russia and Ukraine. Of course, as far as propaganda is concerned, the capabilities of Moscow and Kiev are incomparable. Russia relies on its century-old cultural and historical influence in Bulgaria, as well as on its financial and informational power. The almost complete lack of a language barrier provides Bulgarians of the older generation with access to the Russian media on the Internet and to the Russian state TV, broadcast by almost all cable TV providers in the country. The role of global media, such as Russia Today (RT) TV and the Sputnik News information agency, specifically established in 2014, to disseminate the official position of Russia in English, should also be mentioned. Since the spring of 2015, a Bulgarian language version, created by the media platform Russia Beyond the Headlines, a branch of the Russian newspaper Rossiskaya gazeta, has become operative too. Russia did not have specific propaganda messages with regard to the Ukrainian crisis that were specially developed for the Bulgarian audience. Kremlin's propaganda 
strategists offered some general messages, directed towards all European countries. The most significant among them related to the geopolitical nature of the Ukrainian conflict, which was allegedly created by the Americans in order to restrain the Russian sphere of influence in Eurasia. As regards Russian tactics, Moscow made efforts to antagonize the relationship between the Europeans and the Americans and to exert pressure over the weak members of the EU in order to destroy the consensus over the sanctions. Greece, Hungary and Cyprus, but not Romania and Bulgaria, have been considered as a potential Russian supporters in the EU, that could veto the prolongation of the sanctions but it has never happened.

Unlike in Romania, the Russian propaganda has been well accepted by a substantial part of Bulgarian society including some political and intellectual circles in Bulgaria. One of the main reasons for the pro-Russian sentiments among Bulgarians is historical. The modern Bulgarian state was created in the 19th century after the victorious war of the Russian empire against the Ottomans. In the first half of the 20th century, Bulgaria lost its hope to incorporate Macedonia - the region that was considered as a part of Bulgarian national territory. In the light of the Ukrainian crisis, pro-Russian political and intellectual circles portrayed Crimea, and even the whole Ukraine, as "the Russian Macedonia" (Grigorova 2014). This assertion was used to explain "the historical right" of Russia to return Crimea to the Motherland.

The statement of one of the most popular Bulgarian nationalists, the director of the National History Museum, Bozhidar Dimitrov, is a good illustration of these sentiments: "In 1954 a drunkard gave Crimea, a Russian territory populated with Russians, to a fictional state, to a "Macedonia of a kind". Let us face the truth Ukraine is the Russian Macedonia. Ukrainian borders are as fictional as the Macedonian" (Offnews 2015).

The view that, from a historical perspective, the Ukrainian nation has been "artificially created" in exactly the same manner as that of Macedonian nation, was widespread among pro-Russian, anti-liberal and nationalist circles in Bulgaria.

In turn, Ukraine attempted to promote its perspective mainly through the active presence of its ambassador in the Bulgarian media and during public events. As 
he is an ethnic Bulgarian, he speaks Bulgarian fluently, and this has, from the outset, facilitated an effective communicative engagement with the Bulgarian audience. Of course, the effects of the efforts of the Ukrainian ambassador have been much more modest if we compare it with the results of the Russian propaganda.

\section{GAS, AGRICULTURAL PRODUCTS AND TOURISM - THE ECONOMIC IMPACT OF THE UKRAINIAN CRISIS ON ROMANIA AND BULGARIA}

In the initial stage of the crisis in Ukraine, the policy-makers in Romania had already stressed that Romania was the least dependent on Russian gas, which provided the country with more freedom in shaping its stance on the crisis and the opportunity to actively participate in its settlement. In mid-April 2014, the governor of the Romanian National Bank, Mugur Isărescu, stated that given the limited exports to Russia and Ukraine, the relatively low dependence on Russian gas and the lack of direct links between the Romanian banking sector and the financial institutions of the two countries, Romania was not exposed to significant economic risks in the context of the current geopolitical conflict (Mediafax, 2014). Yet, Russia's decision of August 7, 2014 to impose a ban on the import of fish, dairy products, fruits and vegetables from the EU, in response to the EU sanctions for Russian banks and energy companies with regard to the conflict in Ukraine, had a serious economic impact on Romania, which annually exported foodstuffs to Russia, worth almost 40 million Euro (Chiriac 2014). In this regard, Romanian Prime Minister, Victor Ponta, made a statement that Romania was actually affected by the Russian sanctions but the country had to meet its commitments and assume the responsibility to show that that nobody might change international law, so that it was a price worth paying (Agerpres 2014d).

The Bulgarian economy was not seriously affected by the sanctions imposed by the EU on Russia and the counter-sanctions that were Moscow's response. The 
Bulgarian agriculture export market is modest and only $2 \%$ of it is destined for Russia. For the period August-December 2014, the export of Bulgarian agriculture products to Russia declined by $2,7 \mathrm{mln}$. BGN (1,38 mln. Euro) (Investor.bg 2015).

The number of Russian tourists at the Bulgarian seaside decreased in 2015, but its cause was mainly as the result of the devaluation of the Russian national currency and not because of the political tension between Sofia and Moscow (Gazeta.ru 2015). However, the Ukrainian events have had an indirect reflection on the energy sphere. One of the results of the Ukrainian crisis was the European Commission's full freezing of the negotiations on the South Stream gas pipeline project. This freezing came as part of the economic sanctions against Russia though the South Stream officially was not on the list of the sanctions measures against Moscow. Bulgaria was obliged to comply with the EU energy law and, in the summer of 2014, the then Bulgarian Prime Minister declared all works on the project on Bulgarian territory had to cease (The Guardian 2014).

In October 2014, Gazprom reduced the gas supplies to Romania several times. Against this background, a major scandal broke out with the oil company "Lukoil", whose refinery in southern Romania was closed in connection with checks for tax evasion and money laundering. Although formally there was no connection between the gas supply and the investigation of the Romanian authorities, according to some media, that was a sign that the tense relations between Romania and Russia were exacerbated. It was only a week later, that "Lukoil" resumed production at the Petrotel refinery in the Romanian city of Ploiesti, but the tension between the two countries remained (Nicut 2014).

In early November 2014, Romanian Prime Minister Victor Ponta stated that the Russian Federation posed the most serious risk to the security of Romania. He added that the main weapon of the Russian Federation's energy, so Romania must become energy independent (Agerpres 2014a). Two months later, Ponta reiterated his opinion that the relations of Romania with the Russian Federation will worsen in the short and medium term due to the conflict in eastern Ukraine and because of irreconcilable interests of both countries with regard to the Republic of Moldova (Agerpres 2015d). In an interview shortly after his inauguration, the new Romanian president, Klaus Iohannis, when asked about 
the relations with Russia, said it was a "complex issue" and that Romania had no other way but to work together with its partners (Toea 2015).

\section{ROMANIAN AND BULGARIAN MINORITIES IN UKRAINE AND THE BILATERAL RELATIONS}

According to the latest census organized in Ukraine in 2001, the combined number of Romanians / Moldovans was 410,000, which comprises $0.8 \%$ of the population. About two-thirds defined themselves as Moldovans - 258,619 - and 150,989 as Romanians (State Statistic Committee of Ukraine 2001). The majority of this population reside in the border areas of Romania and the Republic of Moldova. Romania's official position, however, is that they are all Romanians, making them the second largest ethnic minority in Ukraine after Russians.

Bulgarian minority in Ukraine is concentrated mainly in the district of Odessa. According to the 2001 census, this minority consists of 205,000 people. $64.2 \%$ of them identified Bulgarian as their mother tongue, 30.3\% Russian, and 5\% Ukrainian (State Statistic Committee of Ukraine 2001).

The Romanian government continually insisted upon the respect of the collective rights of Romanians in Ukraine and upon reciprocity in the attitude towards the Romanian minority in Ukraine and the Ukrainian minority in Romania. A significant breakthrough in their bilateral relations was made in the summer of 2012, when the Ukrainian government adopted the Law on the Principles of the State Language Policy, which allowed the use of two official languages in the territories where ethnic minorities exceeded $10 \%$ of the population. After this Act entered into force, on August 10, 2012, Romania became the official language in several regions of Western Ukraine (Iglesias 2014). In a press release of late January 2014, the Romanian Ministry of Foreign Affairs expressed concern regarding the situation of the Romanian community in Ukraine, which was on the brink of a civil war and called for dialogue as the only way to solve the crisis, stressing the need to refrain from the use of force (Ziare.com 2014c). 
Romania welcomed the new government in Ukraine, which took office on February 23, 2014, but, at the same time, manifested strong disagreement with the proposed legislative amendments, in particular, the repeal of the above mentioned Law on the language policy, which was perceived as a "blow to the Romanians in Ukraine". President Traian Băsescu stated that "the only way Ukraine could remain united was by respecting the rights of the minorities, including the Russian minority, which should also have the right to express itself in its mother tongue", while the Romanian Ministry of Foreign Affairs underlined the fact that, if Ukraine intended to follow the European path, it had to respect the rights of the minorities (Ziare.com 2014d). A few months later, in connection with the escalation of the conflict in Ukraine and its spread also to the Odessa region, the Romanian president insisted that in case, after the negotiations between the authorities in Kiev and the separatists, an agreement was reached to retain Russian as an official language, the Romanians should also benefit from the same rights (Toea 2014a).

In the course of the crisis in Ukraine, both the Romanian and Bulgarian states began to focus increased attention upon their respective minorities there, and to provide an enhanced voice for the problems that it faced. On June 15, 2014, in the city of Izmail, in the Odessa region, a meeting was held of the Romanian communities from southern Bessarabia, organized by the National-Cultural Association "Bessarabia" of the Romanians from the region of Odessa and the Romanian Cultural Institute in Bucharest. At that meeting, the main problems facing the Romanian community in Ukraine were discussed. The most important among them: the assimilation encouraged by the Ukrainian state, the preservation of their identity, the closure of Romanian schools and the concerns that young Romanians would be mobilized to protect the eastern Ukrainian border. These concerns were encapsulated by the situation of the Romanians in Southern Bessarabia in the Odessa region and in Northern Bukovina in the region of Hertza, where they were subjected to a very strong assimilation pressure. The President of the Odessa Association, Anatol Popescu, stated that the main problem of the Romanian community in the Odessa region was the insufficient number of schools providing education in Romanian and their 
funding, while at the same time he addressed a serious reproach to Romania, which had "abandoned" the community since 1940 (Romanian Parliament 2014). In an interview for a Romanian news site, the Romanian journalist and political scientist from Chernivtsi, Gheorghe Bodnăraş, stated that, due to the policy of the Party of Regions, led by Viktor Yanukovych, the Romanian community in Ukraine was quite divided, but "the life of the Romanians in Ukraine was significantly complicated by the populist statements of extremist forces, who claimed that Romania would regain Northern Bukovina. Similar allegations, he said, were badly perceived by Ukrainian nationalists who had started to regard differently the Romanians and Romania and to present it in the Ukrainian media as an enemy, along with Russia. He drew the attention to the fact that, apart from the everyday problems common to all Ukrainian citizens, regardless of their ethnic origin, Romanians in Ukraine faced also other problems, such as: insufficient funds to develop their own culture and to maintain and develop educational institutions in their native language, obstacles to maintain contact with Romanians abroad, as well as a lack of adequate support from the Romanian state" (Robu 2014).

In early October 2014, the Romanian and Ukrainian authorities, in Kiev, signed an agreement on small border traffic, which regulated the frequent crossing of the Romanian-Ukrainian border by residents of the border areas who planned to remain in the border area of the other state for a period not exceeding three months of uninterrupted stay (Agerpres 2014b). Beyond the signing of the agreement, during a trilateral meeting in Kiev with the Ukrainian and the Moldovan prime ministers, the Romanian Prime Minister Victor Ponta promised to call for the general lifting of the visa requirement for Ukrainian citizens wishing to enter Romania and the EU "as soon as possible" as it had already happened with Moldova within the framework of the Eastern Partnership Viza Free Agreement (Agerpres 2014c).

One more common element in the positions of Romania and Bulgaria towards the Ukrainian crisis has been the concern regarding the mobilization of ethnic Romanians and Bulgarians to serve in the Ukrainian army in 2014-2015. Both Romania and Bulgaria received assurances from Kiev that ethnic Romanians and Bulgarians were not treated differently from the rest of the population of the 
country. In early February 2015, in a conversation with the Ukrainian Ambassador to Bucharest, Teofil Bauer, the Romanian Foreign Minister, Bogdan Aurescu, expressed the expectations of his country that the partial mobilization that was carried out at the height of the conflict in eastern Ukraine would not have a "selective" nature and would avoid "a discriminatory approach along ethnic lines." Aurescu said that Romania "closely monitored" the way the fourth phase of the partial mobilization was being carried out and was in constant contact with the representatives of ethnic Romanians and the Ukrainian civil and military authorities through the General Consulate in Chernivtsi and Odessa. Bauer assured him that all legal requirements would be met and discrimination will not be allowed (Agerpres 2015b). During the visit of the Ukrainian Foreign Minister, Pavlo Klimkin, to Bucharest in mid-February 2015, Bucharest again received assurances that there was no discrimination on ethnic grounds in Ukraine and, with regard to mobilization, it was indicated that in the two regions located near the border with Romania with a total population of 100,000 inhabitants only 25 people were mobilized (Mihai 2015).

In February 2015, Pavlo Klimkin visited Sofia and also provided the same assurances to the Bulgarian authorities - the proportion of ethnic Bulgarians mobilized in the Ukrainian army was equal to their proportion of the total Ukrainian population. These assurances did not satisfy nationalist political parties in Bulgaria and they insisted that Bulgarians from Ukraine should be able to obtain Bulgarian citizenship in a fast-track procedure and to settle in Bulgaria with the assistance of the state. Regarding this aspect, we have to note that 6000 Ukrainians had obtained Bulgarian citizenship in 2001-2015 but most of them had not wanted to live in Bulgaria. It is worth mentioning the existence of Bulgarian minority in the separatist regions of Donetsk and Luhansk, where the armed conflict took place in 2014-2015. There are 4833 Bulgarians in the Donetsk district another 1625 are living in the Luhansk district.

According to the Law on the Principles of the State Language Policy, Bulgarian language should be official in 7 regions of the Odessa district and also in the town of Izmail. However, this has only been implemented in the Bolgrad region, where Bulgarians are more than $60 \%$ of the population. It was clear that the introduction of the Bulgarian language as an official language in the Ukrainian 
regions with substantial Bulgarian minority was mainly a symbolic act. Almost all Bulgarians in Ukraine speak Russian and have never had problems to communicate with the local administration.

\section{CONCLUSION}

The crisis in Ukraine has been a serious challenge to the foreign policy of Romania and Bulgaria, which had to act from the position of member states of the EU and NATO and Black Sea countries. The Ukrainian events of 2013-2015 turned out to be a touchstone for the ability of Romania and Bulgaria to coordinate their positions on important international issues with their EU partners.

Romania perceived the Ukrainian crisis as an opportunity to strengthen its influence and strategic role and to become a key player in the Black Sea region. It was among the strongest supporters of Western sanctions against Russia, condemned Russia's actions in Ukraine, and continuously pushed for greater firmness and determination on the part of its European partners towards Moscow and called for enhanced NATO presence in the Black Sea region and on its own territory. At the same time, Bulgaria was in the group of the European states which maintained a moderate line towards Russia. The anti-Russian sanctions were accepted in Sofia as an inevitable affliction.

In regard to the Ukrainian crisis, Romania and Bulgaria followed the dominant position within the EU without actively participating in its shaping. Germany has had a leading role in the defining of the EU's reaction toward the UkrainianRussian conflict. Naturally, Berlin's position has been refracted through the prism of Brussels since the European Commission, as a supra-national body, also has its specific role in forming the European policy toward Russia and Ukraine. This fact enabled the Romanian and Bulgarian governments to take a comfortable position within the surrounding European consensus without being obliged to refer to the tacit German leadership or to any initiative of its own. 
Romania's firm position with regard to the Ukraine crisis could not but aggravate its relations with Russia. Actually, the concern in relation to Moldova was a central determinant in formulating Romania's position on the crisis in Ukraine. The Romanian government had good relations with the Ukrainian leaders after Yanukovych and used every opportunity to raise the issue regarding the ethnic Romanian minority in Ukraine.

The Ukrainian crisis had an enduring impact on the Romanian and Bulgarian public debates on international politics. The necessity of adopting a position on the conflict between Kiev and Moscow has added new aspects to the meaning of the Romanian and Bulgarian membership in the EU and NATO. Many Romanians and Bulgarians have realized that the EU is not confined to a common market and freedom of movement but also extends to the definition of common values and their protection and enforcement in the international arena. In recent years, NATO has focused on the threats emerging from remote parts of the world outside the Euro-Atlantic Zone. The annexation of Crimea, the subsequent increased Russian military and political activity in the Black Sea region, were a turning point marking the end of the "post-geographic period" in NATO's development. Thus, the Ukrainian crisis conferred a new meaning upon the Bulgarian and Romanian membership in the North Atlantic Pact, which is now viewed through the prism of the necessity for conventional measures of territorial defence. After 2014, Romania and Bulgaria have become a part of the threatened Eastern flank of NATO, which the Alliance's strategists plan to strengthen by deploying additional mobile military formations and equipment and holding more frequent joint military exercises of the partners' armies.

Both Romania and Bulgaria have a long history of complicated relations with the Russian empire, the Soviet Union and the Russian Federation that has influenced their positions toward the Ukrainian-Russian conflict in 2014-2015. The majority of the Romanian society and their political representatives have supported Ukraine, while the situation in Bulgaria was different because of the traditional pro-Russian sentiments of a substantial part of the Bulgarian society. However, despite these differences, EU membership has been a central factor that has encouraged the convergence of the official positions of Bulgaria and Romania towards the Ukrainian crisis. 


\section{REFERENCES}

- PM Ponta: Romania affected by Russia sanctions, but must meet commitments, Agerpres September 12, 2015. Accessed December 1, 2015. http:/ / www.agerpres.ro/english/2014/09/12/ pm-ponta-romania-affected-by-russiasanctions-but-must-meet-commitments-13-48-59

- $\quad$ ForMin Aurescu tells Ukraine Romania expects mobilization to not be 'selective', Agerpres February, 3, 2015. Accessed December 1, 2015. http:/ / www.agerpres.ro/english/2015/02/03/formin-aurescu-tells-ukraine-romaniaexpects-mobilization-to-not-be-selective--15-55-38

- Mariupol attack a test for international community, including EU reaction, Agerpres January 30, 2015. Accessed December 1, 2015. http:/ / www.agerpres.ro/english/2015/01/30/mariupol-attack-a-test-for-internationalcommunity-including-eu-reaction-14-33-54

- PM Ponta: I see worsened relations of Romania with Russia on short- and medium-term, Agerpres January 22, 2015. Accessed December 1, 2015. http:/ / www.agerpres.ro/english/2015/01/22/ pm-ponta-i-see-worsened-relations-ofromania-with-russia-on-short-and-medium-term-18-24-49

- PSD's Ponta: Russian Federation, highest security risk for Romania, Agerpres, November 10, 2014. Accessed January 15, 2016. .http:/ / www.agerpres.ro/english/2014/11/10/psd-s-ponta-russian-federation-highestsecurity-risk-for-romania-10-09-20

- PMs Ponta, Yatsenyuk sign Romania-Ukraine small border traffic agreement, Agerpres, October 2, 2014. Accessed January 15, 2016. http:/ / www.agerpres.ro/english/2014/10/02/pms-ponta-yatsenyuk-sign-romaniaukraine-small-border-traffic-agreement-17-52-37

- PM Ponta: Romania to call for visa lifting for Ukraine as soon as possible, Agerpres, October 2, 2014. Accessed January 15, 2016. http:/ / www.agerpres.ro/english/2014/10/02/ pm-ponta-romania-to-call-for-visa-liftingfor-ukraine-as-soon-as-possible-19-23-05

- PM Ponta: Romania affected by Russia sanctions, but must meet commitments, Agerpres, September 12, 2014. Accessed December 18, 2015. http:/ / www.agerpres.ro/english/2014/09/12/pm-ponta-romania-affected-by-russiasanctions-but-must-meet-commitments-13-48-59

- Traian Basescu: After Newport summit Romania too has contingency, action plans in case it is attacked, Agerpres, September 7, 2014. Accessed December 15, 2015. http:/ / www.agerpres.ro/english/news-of-the-day/2014/09/07/traian-basescu-afternewport-summit-romania-too-has-contingency-action-plans-in-case-it-is-attacked-19-3536

- Titus Corlățean: 'Sprijinim o prezență consistentăa NATO pe flancul său estic, atât tim cât va fi necesar', Agerpres, September 3, 2014. Accessed December 22, 2015). 
http:/ / www.agerpres.ro/politica/2014/09/03/titus-corlatean-sprijinim-o-prezentaconsistenta-a-nato-pe-flancul-sau-estic-atat-timp-cat-va-fi-necesar--22-06-53

- MAE: Russia's Rogozin's threat to use a fighter jet, a very serious declaration, Agerpres, May 10, 2014. Accessed December 2015. http:/ / www.agerpres.ro/english/2014/05/10/mae-russian-formin-s-threat-to-use-afighter-jet-a-very-serious-declaration-16-40-13

- $\quad$ Badea, C. "Ponta despre Ucraina: Romania nu are si nu trebuie sa aiba actiuni proprii". Ziare.com, March 14, 2014. Accessed December 13, 2015. http:/ / www.ziare.com/victor-ponta/ premier/ponta-despre-ucraina-romania-nu-are-sinu-trebuie-sa-aiba-actiuni-proprii-1287783

- Ukraine sanctions imposed amid Kiev clashes, BBC News, February 21, 2014. Accessed December 1, 2015). http://www.bbc.com/news/world-europe-26280710

- The Security Council edited 5 sentences in "Vision 2020" and adopted it. (Съветът за сигурност редактира 5 изречения във „Визия 2020” и я прие), Capital. September 1, 2014. Accessed December 15, 2015. http://www.capital.bg/politika_i_ikonomika/bulgaria/2014/09/02/2373334_suvetut_za _sigurnost_redaktira_5_izrecheniia_vuv/

- $\quad$ The document that declared Russia as a threat, has been withdrawn. (Оттеглен е документът за НАТО, който обявяваше Русия за заплаха), Capital, August 27, 2014. Accessed December 15 , 2015. http://www.capital.bg/politika_i_ikonomika/bulgaria/2014/08/27/2369750_otteglen_e _dokumentut_za_nato_koito_obiaviavashe/

- Chiriac, M. "Romania Weighs Cost of Russian Import Ban." Balkan Insight,

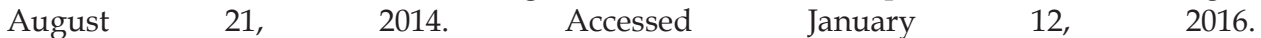
http:/ / www.balkaninsight.com/en/article/romania-hit-by-russia-s-food-ban

- Club "Z”. Vigenin gave his support to the new rulers in Kiev. (Вигенин подкрепи $b$ Киев новите управляващи). March 4, 2014. Accessed January 12, 2016. http://clubz.bg/1311-vigenin_podkrepi_v_kiev_novite_upravlqvashti

- $\quad$ Cross. CCNS: We do not recognize the results of the referendum in Crimea. (KCHC: He признаваме резултатите от референдума В Крим), March 24, 2014. Accessed January 20, 2016. http://www.cross.bg/bulgariya-ykraiina-rysiya-1402625.html\#.VXmQLPntlHw

- $\quad$ Bulgarian members of the European Parliament insisted for new government and presidential elections in Ukraine. (Български евродепутати настояха за ново правителство и президентски избори в Украйна), Dnevnik, February 20, 2014. Accessed December 10, 2015. http:/ /www.dnevnik.bg/evropa/evropeiski_parlament/novini_za_ep/2014/02/20/22 46194_bulgarski_evrodeputati_nastoiaha_za_novo_pravitelstvo/

- A quotation of the day: A happy victory in the Crimean war to all Ortodox slavs" (Цитат на деня: Честита победа в Кримската война на православните славяни), Dneonik., March 19, 2014. Accessed December 5, 2015.http://www.dnevnik.bg/citat_na_deniia/2014/03/19/2264223_citat_na_denia_chest ita_pobeda_v_krimskata_voina_na/ 
- Political and Economic Index - April 2014. (Политически и икономически индекс anpur 2014 2.). Gallup International. $2014 . \quad$ http://www.gallupinternational.bg/bg/\% D0\%9F\%D1\%83\%D0\%B1\%D0\%BB\%D0\%B8\%D0\%BA\%D0\%B0\%D1 \%86\%D0\%B8\%D0\%B8/78-2014/184-Political-Economic-Index-April-2014

- $\quad 30 \%$ less Russian tourists have gone abroad in this summer. (Pocсuйcкuй myрnomoк за рубеж за лето упал на 30\%), Gazeta.ru, August 5, 2015. Accessed December 5, 2015. http://www.gazeta.ru/lifestyle/news/2015/08/05/n_7436965.shtml

- $\quad$ Gediminas, Vitkus. "Towards Stronger Normative Power: the Nature of Shift in EU Foreign Policy in the Context of the Crisis in Ukraine," European Integration Studies, 9 (2015).

- $\quad$ Grigorova, D. "Will Ukraine turn into a "fire wall" between Russia and Europe?" (Ще се превърне ли Украйна В „огнена стена” между Русия и Европа?) Glasove, May 8, 2014. Accessed December 15, 2015. http://glasove.com/categories/interviuta/news/docdarina-grigorova-shte-se-prevyrne-li-ukrajna-v-ognena-stena-mejdu-rusiq-i-evropa

- Traian Basescu, apel la Vladimir Putin sa condamne ferm actiunile din regiunea Donetsk si sa isi utilizeze autoritatea pentru a permite functionarea misiunii OSCE, HotNews.ro, April 28, 2014. Accessed December 20, 2015. http://www.hotnews.ro/stiriesential-17125999-traian-basescu-retinerea-reprezentantilor-osce-este-atac-direct-eforturileinternationale-detensionare-situatiei-romania-condamna-orice-separatism-utilizareapresiunilor-tip-militar.htm

- Iglesias, Julien Danero. "Ukraine, Romania, and Romanians in Ukraine", Südosteuropa 62 (2014), no. 3 : 379.

- $\quad$ Ilie, A. "Efectul crizei din Ucraina asupra R. Moldova si parghiile UE. Interviu." Ziare.com, February 27, 2014. Accessed January 11, 2016. http:/ / www.ziare.com/europa/moldova/efectul-crizei-din-ucraina-asupra-r-moldova-siparghiile-ue-interviu-1285023

- $\quad$ Inayeh, A. "Romania: Largely Immune to Russian Pressures." In: Forbrigi, J. (ed.), A Region Disunited? Central European Responses to the Russia-Ukraine Crisis. Europe Policy Paper, February 2015, p. 42. http://www.gmfus.org/publications/region-disunitedcentral-european-responses-russia-ukraine-crisis

- INSCOP Research. Sondaj INSCOP, July 30, 2014 . http://www.inscop.ro/31iulie-2014-dcnews-sondaj-inscop-ce-tari-simpatizeaza-si-antipatizeaza-romanii-germaniasi-rusia-la-extreme/

- Investor.bg. Bulgarian agriculture export to Russia shrank with 4,4\% because of the sanctions. (Санкиците са свили износа на селскостопански стоки към Русия с 4,4\%). Мау 15, 2015. Accessed December 10, $2015 . \quad$ http://www.investor.bg/ikonomika-ipolitika/332/a/sankciite-sa-svili-iznosa-na-selskostopanski-stoki-kym-rusiia-s-44-194760/ - Kalan, D. "Bulgaria's Turn. Sofia Gives Moscow Some Attitude." Foreign Affairs, June 9, 2015. https://www.foreignaffairs.com/articles/bulgaria/2015-06-09/bulgariasturn 
- $\quad$ Kirilov, V .\& Putincev, I. "Отношения России и Румынии после 1989 года в контексте внешнеполитических приоритетов двух стран." (The relations between Russia and Romania after 1989 in the context of the foreign policy priorities of the two countries). Вестник МГИМО-Университета 23 (2012), nо. 3: 13-24.

- $\quad$ Kruglashov, A. "Troublesome neighborhood: Romania and Ukraine relationship." New Ukraine. A Journal of History and Politics, 11 (2011): 114-125. http://www.nowaukraina.org/nu_11_2011/09_Kruhlaszov.pdf

- $\quad$ Lessenski, M. "Bulgaria: Increasingly Assertive but not Hawkish. In: Forbrigi, J. (ed.), A Region Disunited? Central European Responses to the Russia-Ukraine Crisis. Europe Policy Paper, February 2015, p.7. http://www.gmfus.org/publications/region-disunitedcentral-european-responses-russia-ukraine-crisis

- $\quad$ Mândrăşescu, V. "Bucureştiul zăngăne armele." Vocea Rusiei, May 12,2014. Accessed December 22, 2015. http://romanian.ruvr.ru/2014_05_12/BucureStiul-zanganearmele-3374/

- Isărescu, despre conflictul Rusia-Ucraina: România nu este expusă la riscuri economice semnificative, Mediafax, April 24, 2014. Accessed December 20, 2015. http:// www.mediafax.ro/economic/isarescu-despre-conflictul-rusia-ucraina-romania-nueste-expusa-la-riscuri-economice-semnificative-12517325

- $\quad$ Plevneliev: For us Crimea is Ukraine, and Ukraine is Europe. (Плевнелиев: За нас Крим е Украйна, а Украйна е Европа),Mediapool, July 7, 2015. Accessed January 12, 2016. http://www.mediapool.bg/plevneliev-za-nas-krim-e-ukraina-a-ukraina-e-evropanews236365.html

- Borisov about Russia: We do not want to break up the relations with a brotherhood nation. (Борисов за Русия: Не искаме да прекъсваме отношенията с един братски народ), Mediapool, May 15, 2015. Accessed January 12, 2016. http://www.mediapool.bg/borisov-za-rusiya-ne-iskame-da-prekasvame-otnosheniyata-sedin-bratski-narod-news234075.html

- $\quad$ BSP: Never against Russia, never against the European Union. (БСП: Никога срещу Русия, никога срещу Европейския съюз), Mediapool, March 16, 2014. Accessed January 12, 2016. http://www.mediapool.bg/bsp-nikoga-sreshtu-rusiya-nikoga-sreshtuevropeiskiya-sayuz-news217990.html

- $\quad$ Mihai, C. "Pavlo Klimkin: Nu există discriminare pe criterii etnice în ceea ce priveşte mobilizarea din Ucraina." Mediafax, February 17, 2015. http:/ / www.mediafax.ro/externe/pavlo-klimkin-nu-exista-discriminare-pe-criteriietnice-in-ceea-ce-priveste-mobilizarea-din-ucraina-13839786

- Milevska, T. "Anxiety grows in Europe as Transnistria asks for Russian annexation." Euractive, March 19, 2014. https://www.euractiv.com/section/europe-seast/news/anxiety-grows-in-europe-as-transnistria-asks-for-russian-annexation/

- Ministry of Foreign Affairs. Comunicat de presă privind condamnarea aşa-ziselor "referendumuri" din regiunile Donețk și Lugansk. May 11, 2014. http://www.mae.ro/node/26605 
- Ministry of Foreign Affairs. Vizita în SUA a ministrului afacerilor externe, Titus Corlătean (29-30 Aprilie 2014). April 28, 2014. http://www.mae.ro/node/26251

- Ministry of Foreign Affairs. The OSCE monitoring mission to be deployed in Ukraine, March 22, 2014. http://www.mae.ro/en/node/25592

- $\quad$ Nicuț. M. "Ziua Z pentru Petrotel. De ce ar încide ruşii de la Lukoil cea de-a treia rafinărie a României." ECONOMICA.net, October 10, 2014. Accessed December 22, 2015. http:/ / www.economica.net/ziua-z-pentru-petrotel-de-ce-ar-inchide-azi-rusii-de-la-lukoilcea-de-a-treia-rafinarie-a-romaniei_89274.html

- Bozhidar Dimitrov: Ukraine is an imagined state, it is the "Russian Macedonia." (Божидар Димитров: Украйна е измислена държава, тя е „руската Македония”), Offnews, February 13, 2015. Accessed December 17, 2015. http://offnews.bg/news/Politika_8/Bozhidar-Dimitrov-Ukrajna-e-izmislena-darzhavatia-e-ruskata-Makedo_462089.html

- $\quad$ PES website, News. PES denounces illegal referendum in Crimea, April 17, 2014. http://www.pes.eu/pes_denounces_illegal_referendum_in_crimea

- Political Party "Ataka" official web-site, April 4, 2014. http:/ / www.ataka.bg/index.php?option=com_content\&task=view\&id=6853\&Itemid=74

- $\quad$ Regulation (EU) №269/2014 Official Journal of the European Union, p.78/6-78/10, March 17, 2014.

- $\quad$ Robu, D. "Romanii din Ucraina sunt divizati. Romania, vazuta in presa ca un vrajmas, la fel ca Rusia." Ziare.com, June 20, 2014. Accessed December 10, 2015. http://www.ziare.com/diaspora/romani-strainatate/romanii-din-ucraina-sunt-divizatiromania-vazuta-ca-un-vrajmas-la-fel-ca-rusia-interviu-1306746

- Romanian Parliament. 2014. Comisia pentru comunitățile de români din afara granițelor țării SINTEZA lucrărilor Comisiei din zilele de 17, 18 şi 19 iunie 2014. http://www.cdep.ro/comisii/diaspora/pdf/2014/sz0617.pdf

- $\quad$ Serban, L. "President Basescu at the Nuclear Security Summit in the Hague." Nineo'clock.ro, March 24, 2014. Accessed December 20, 2015. http:/ / www.nineoclock.ro/ president-basescu-at-the-nuclear-security-summit-in-thehague/

- $\quad$ Serghescu, A. "Criza din Ucraina: Este Romania in pericol? Ce spune Victor Ponta." Ziare.com, April 17, 2014. Accessed December 10, 2015. http:/ / www.ziare.com/victor-ponta/premier/criza-din-ucraina-este-romania-in-pericolce-spune-victor-ponta-1294362

- Les intérêts roumains en Ukraine, Sputnik France, April 22, 2014. Acceessed December 17, 2015. https://fr.sputniknews.com/actualite/201404221022788182-lesinterets-roumains-en-ukraine/

- $\quad$ State Statistic Committee of Ukraine (2001) All-Ukrainian population census'2001 data; http://2001.ukrcensus.gov.ua/eng/results/general/nationality/

- Putin blames EU as Russia abandons plans for South Stream gas pipeline, the Guardian,

December

1 ,

2014. 
https://www.theguardian.com/business/2014/dec/01/russia-blames-eu-as-it-abandonsplans-for-south-stream-gas-pipeline

- Romanian military units moving towards Ukrainian border, the Voice of Russia, April 27, 2014. Accessed December 2015. https://sputniknews.com/voiceofrussia/news/2014_04_27/Romanian-military-unitsmoving-towards-Ukrainian-border-2722/

- $\quad$ Toea, D. "Klaus Iohannis vorbeste in presa germana despre amenintarea Rusiei si reputatia Romaniei." Ziare.com, February 26, 2015. Accessed December 18, 2015. http://www.ziare.com/klaus-johannis/presedinte/klaus-iohannis-vorbeste-in-presagermana-despre-amenintarea-rusiei-si-reputatia-romaniei-1350053

- $\quad$ Toea, D. "Basescu: Cerem ca minoritatea Romana din Ucraina sa se bucure de aceleasi drepturi ca cea rusa." Ziare.com, May 13, 2014. Accessed December 18, 2015. http:/ / www.ziare.com/basescu/presedinte/basescu-cerem-ca-minoritatea-romana-dinucraina-sa-se-bucure-de-aceleasi-drepturi-ca-cea-rusa-1298748

- $\quad$ Toea, D. "Basescu: Rusia doreste destabilizarea Ucrainei. Am avut prea multa incredere in Putin." Ziare.com, May 13, 2014. Accessed December 18, 2015. http://www.ziare.com/basescu/presedinte/basescu-rusia-doreste-destabilizareaucrainei-pentru-a-o-pune-sub-control-1298722

- Toea, D. "Basescu, despre criza din Ucraina: Ce a facut Rusia e o agresiune, Romania trebuie sa se implice." Ziare.com, March 6, 2014. Accessed December 18, 2015. http:/ / www.ziare.com/international/ucraina/criza-din-ucraina-basescu-spuna-caromania-trebuie-sa-se-implice-1286232

- $\quad$ Zachmann, S.\& A. Boghiceanu. "Băsescu, la Adevărul Live: Nu cred că vreo țară NATO ar fi atacată de Federația Rusă. Ar fi război." Adevărul, April 23, 2014. Accessed December 21, 2015. http://adevarul.ro/news/politica/traian-basescu-adevarul-live-ora1100-1_53576a890d133766a8044e53/index.html

- $\quad$ Tariceanu: Romania sa face demersuri sa fie inclusa intre tarile amenintate de conflictul ucrainean, Ziare.com. April 17, 2014. Accessed December 5, 2015. http://www.ziare.com/tariceanu/senat/tariceanu-romania-sa-faca-demersuri-sa-fieinclusa-intre-tarile-amenintate-de-conflictul-ucrainean-1294328

- Basescu: Referendumul din Crimeea e ilegal, nu recunoastem rezultatele, Ziare.com, March 16, 2014. Accessed December 5, 2015. http:/ / www.ziare.com/basescu/presedinte/basescu-referendumul-din-crimeea-e-ilegalnu-recunoastem-rezultatele- 1288140

- Ministerul roman de Externe, mesaj pentru Ucraina: Protejati minoritatile!, Ziare.com, February 24, 2014. Accessed December 5, 2015. http://www.ziare.com/stiri/mae/ministerul-roman-de-externe-mesaj-pentru-ucrainaprotejati-minoritatile-1284476/

- MAE, cu ochii pe romanii din Ucraina: Dialogul, unica solutie pentru criza, Ziare.com, January 29, 2014. Accessed December 5, 2015. http:/ / www.ziare.com/stiri/mae/mae-cu-ochii-pe-romanii-din-ucraina-dialogul-unicasolutie-pentru-criza-1279953 
- Vigenin: Bulgaria waits for the EU's common position on Ukraine. (Вигенин: България изчаква общата позиция на ЕС за Украйна), 24 chasa, December 2, 2013. Accessed December 10, 2015. https:// www.24chasa.bg/Article/2513160 